\title{
IMPACT OF VISITS ON MICROCLIMATE OF CAVES - AN ANALYTICAL APPROACH
}

\author{
VPLIV OBISKOV NA MIKROKLIMO JAM - \\ ANALITIČNI PRISTOP
}

Jože RAKOVEC ${ }^{1}$

\begin{abstract}
UDC 551.584.6:551.588

Jože Rakovec: Impact of visits on microclimate of caves - An analytical approach

Theoretical basis for describing natural steady state conditions in caves as well as for their changes in time that follow from the simple advection-diffusion equation, is given. The impacts of visits to caves - direct impacts due to anthropogenic emissions of heat and $\mathrm{CO}_{2}$, as well as indirect ones, such as illumination and possible drafts when opening the door to the cave - are estimated in dependence to the number of visitors and the size of the cave: the size with which the effects of the visits are below the detection threshold is estimated. It is shown that the sources cause linear responses, while the consequences of the exchange with the walls of the cave or with the exterior depend on time exponentially. Characteristic times for linear as well as for exponential responses are roughly estimated.

Key words: cave microclimate, analytical solution, heat trans-
\end{abstract}

Izvleček

UDK 551.584.6:551.588 port, carbone dioxide.

Jože Rakovec: Vpliv obiskov na mikroklimo jam - analitični pristop

Podane so teoretične podlage za opis naravnih ravnotežnih pogojev v jamah in za njihove časovne spremembe, kot izhajajo iz preproste advektivno-difuzijske enačbe. Ocenjeni so vplivi obiskov v jame - tako neposredno zaradi antropogenih emisij toplote in $\mathrm{CO}_{2}$, kot posrednih, kot so razsvetljevanje in možni prepihi pri odpiranju vrat $v$ jamo. Velikost teh vplivov je ocenjena glede na število obiskovalcev in glede na velikost jame: ocenjena je velikost, pri kateri so učinki obiskov pod pragom zaznavanja. Pokazano je, da viri povzročajo linearne odzive, medtem ko so posledice izmenjav s stenami jame ali z zunanjostjo eksponentno odvisne od časa. Grobo so ocenjeni karakteristični časi za linearno kot za eksponentne odzive so grobo ocenjeni. Ključne besede: jamska mikroklima, analitična rešitev, prenos toplote, ogljikov dioksid.

\footnotetext{
${ }^{1}$ upokojeni profesor Univerze v Ljubljani, Fakulteta za matematiko in fiziko, Katedra za meteorologijo, Jadranska 19, 1000 Ljubljana, e-mail: joze.rakovec@fmf.uni-lj-si
} 


\section{INTRODUCTION}

Natural microclimatic conditions in caves are characterized by quasi-stationary values of temperature, humidity, $\mathrm{CO}_{2}$ concentration, etc. In closed caves air temperature is determined by the temperature of walls, $\mathrm{CO}_{2}$ concentrations are normally an order of magnitude higher than outside because of specific $\mathrm{CO}_{2}$ tranport mechanisms to caves. These comprise diffusive and advective transport (including the chimney effect) through fractures and openings of both, the gaseous, as well as the $\mathrm{CO}_{2}$ dissolved in water. For example rainwater enriches during percolation through soil due to root respiration as well as from organic matter decay in deeper sources (e.g., Faimon \& Lièbinská 2010; Prelovšek 2012; Ek \& Godissart 2014; Sallsted et al. 2014). But Covington (2016) stresses also the importance of the air-water $\mathrm{CO}_{2}$ exchange in fractures - so several several ways of $\mathrm{CO}_{2}$ transport into caves could generally be relevant. When percolating water reaches the cave the precipitation of calcite is triggered by the quick initial degassing of $\mathrm{CO}_{2}$, folowed by for approx. 3-times slower equilibration to the new $\mathrm{CO}_{2}$ concentration in the cave's atmosphere (Dreybrodt 2011). As regards the air advection with outside through counduits it increases the temperature in the warm part of the year and decreases it in winter, but always decreases the inner $\mathrm{CO}_{2}$ concentration (due to low outside concentration).

The further from the entrance a particular location in a cave is the weaker the influences from the outside. From general principles of diffusion-related processes we may conclude that deeper in the cave the amplitudes due to outer variations get smaller and phase shifts are larger. One borderline case is a widely open cave where close to its entrance outer conditions prevail. The other extreme is reached deep in a narrow cave where the changes caused by outer weather and/or seasonal variations become so small that could no more be detected - such a cave is effectively a closed cave.

In tourist caves visitors also influence the microclimate: with their heat release and the release of $\mathrm{CO}_{2}$ and water vapour due to their metabolism. Indirect impact of visits could be also draughts, heat released by illumination. The more numerous the visitors are, the more frequent the visits are and the smaller the cave is, the greater is the impact. The recovery starts after visitors have left the cave or moved further into other parts of the cave.

Since warm air tends to rise and cold air tends to sink it is reasonable to expect that in summer the warm outer air will normally not sink or mix downwards into concave cave volumes. Only very strong wind may produce enough turbulence to cause some downward mixing. On the other hand cold air during winter will tend to fill concave holes and caves. If a cave has more connections with the outer environment, the air moves into or out of it by draughts or breezes.

The microclimate of caves has been studied by several authors. Monographic publications using deterministic approach are e.g., by Badino (1995), Lismonde (2002 a;b) or Gunn (2004). There are numerous papers in scientific journals about that, e.g., Dreybrodt et al. (2005), Milanolo \& Gabrovšek (2009), Gregorič et al. (2014). The microclimate of caves was also a scope of an international school in karst sciences (Gabrovšek \& Mihevc 2009) and of $\mathrm{PhD}$ theses (Fernández Cortés 2004). There are many reports on microclimate monitoring in caves, e.g., Šebela \& Turk (2011), Prelovšek et al. (2018).

There are not many analytical descriptions of processes in caves depending on both time and space, but some of these start from basic principles (Badino 1995; Dreybrodt et al. 2005) of energy conservation in heat exchange, mass conservation including sources and sinks. In this paper we consider a cave's air equilibria and changes using only one simple principle: that the local value of a certain variable may change in time 1 . due to advection of that variable, 2 . due to sources and sinks and, 3 . in the case when variables are not homogeneous with the cave's volume also due to mixing with neighbouring air. The equation appropriate for such an approach is the advection-diffusion equation called also scalar transport equation, see e.g., Bird et al. (2007) or Becker \& Kaus (2016) and Covington (2015) for water-air $\mathrm{CO}_{2}$ exchanges in karstic fractures. Based on such general approach analytical solutions will be studied for different processes in caves. In particular, we are going to describe equilibrium stationary cases as well as time changes due to visits including their recoveries to natural conditions.

\section{ADVECTION-DIFFUSION EQUATION APPLIED TO CAVE MICROCLIMATE PROCESSES}

Consider a constant air mass $m=$ const. in a cave with volume $V: m=\rho V$. The variables that characterize its state change when there are sources or sinks for that characteristic - for example heat sources/sinks change enthalpy $m c_{p} T$, sources/sinks of $\mathrm{CO}_{2}$ change its concentration $c=m_{\mathrm{CO} 2} / m$. For a constant mass $m$ the 


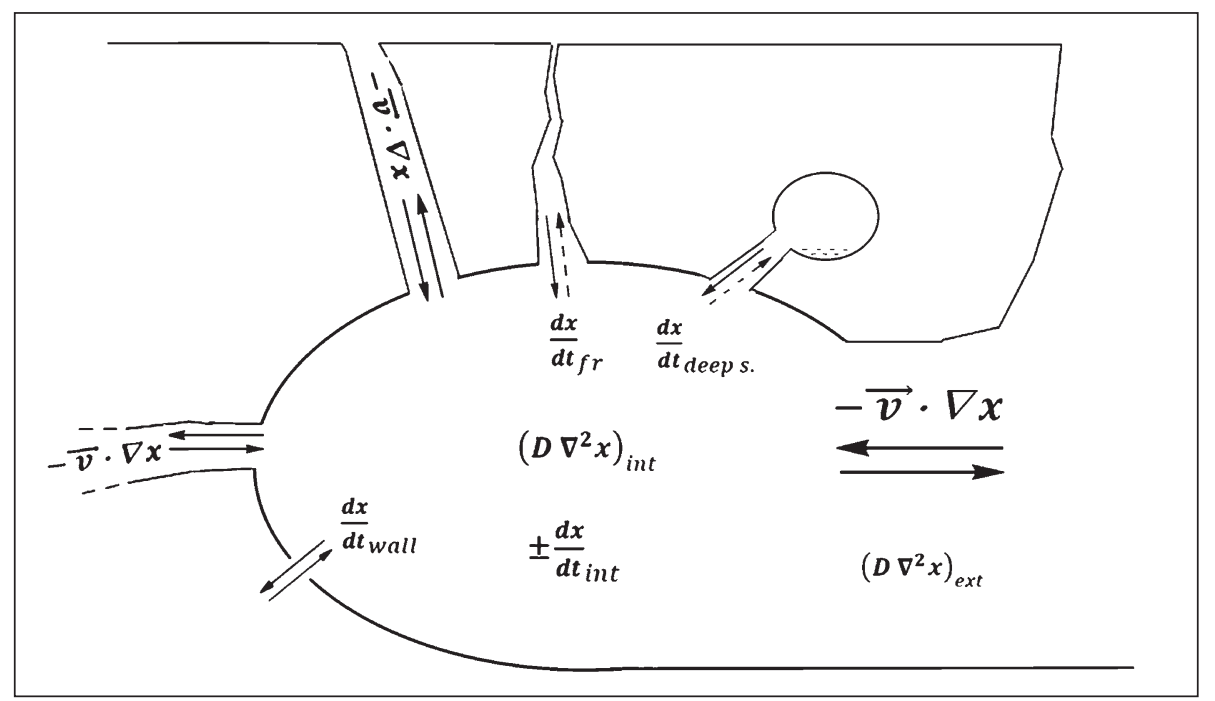

Fig. 1a: Schematic presentation of different sources $\frac{d x}{d t}$ - of matter (in our case $\mathrm{CO}_{2}$ ) or heat $-x$, of advection exchanges $-\vec{v} \cdot \nabla x$ and of diffusion processes $D \nabla^{2} x$.

two individual changes are $d\left(m c_{p} T\right)=m c_{p} d T$ and $d c=d m_{\mathrm{CO} 2} / m$.

Sources for air's enthalpy $m c_{p} T$ are heat sources/ sinks $d Q$ inside the cave as well as heat exchanges with the cave's walls. Adiabatic air expansion or compression influences temperature only if air moves upwards or downwards; phase changes water/vapour are neglected. Divergence of transport due to moving air $\nabla \cdot(\overrightarrow{v T})$ locally changes temperature; as in air $\nabla \cdot \vec{v} \approx 0$ only advection $\vec{v} \cdot \nabla T$ due to breeze with velocity $\vec{v}$ contributes to local change. If there are important fluctuations of velocity $\overrightarrow{v^{\prime}}$ and/or of temperature $T^{\prime}$, local temperature might be affected also by eddy (turbulent) transport $\overrightarrow{\overrightarrow{v^{\prime}} T^{\prime}}$. The divergence of such non-advective eddy transport $\nabla \cdot \overline{\overline{v^{\prime}}} T^{\prime}$ is often simplified in Stokes' manner as $D_{T} \nabla^{2} T$ where $D_{T}$ stands for eddy (turbulent) diffusivity being an order of magnitude greater than the molecular one. So the advection-diffusion equation for local change of temperature $T$ takes the form: $\frac{\partial T}{\partial t}=-\vec{v} \cdot \nabla T+\frac{1}{m c_{p}} \frac{d Q}{d t}+D_{T} \nabla^{2} T$

Analogue reasoning may be applied also for $\mathrm{CO}_{2}$ concentration $c$ :

$\frac{\partial c}{\partial t}=-\vec{v} \cdot \nabla c+\frac{1}{m} \frac{d m_{\mathrm{CO} 2}}{d t}+D_{c} \nabla^{2} c$.

Different terms of such equations are for a cave schematically presented in Fig. 1a ( $x$ denoting either $T$ or $c$ ), while the qualitative ranges and efficiencies of advection and diffusion transports in Fig. $1 b$.

The time changes of air properties $x$ are schematically presented in Fig. $1 \mathrm{a}$; in our case $x$ stands for $\mathrm{CO}_{2}$ or for temperature. The sources/sinks in the cave $\frac{d x}{d t}$ might be internal $\frac{d x}{d t}$ int (e.g. anthropogenic, cave organisms, technical equipment etc.), from surface through fractures $\frac{d x}{d t} f r$, from some deeper sources (e.g. for $\mathrm{CO}_{2}$ from the decaying organic matter or deep $\mathrm{CO}_{2}$ sources), due to echange with walls $\frac{d x}{d t}{ }_{\text {wall }}$, etc. The most

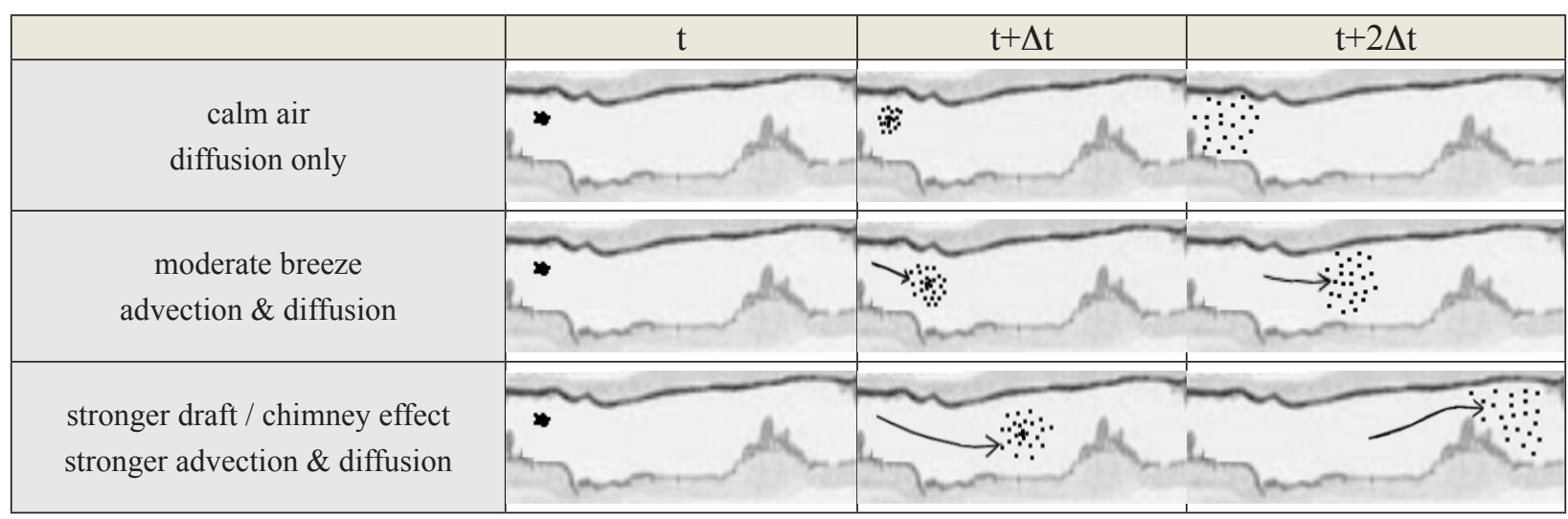

Fig. 1 b: Schematic presentation of range and efficiency of advection and diffusion, represented in three consecutive times. 
important advection exchange $-\vec{v} \cdot \nabla x$ is with the outer environment through channels with various crosssections and open fractures connecting to the surface and/or advection exchanges with other parts of the cave through side channels, and also through fractures. Advection is commonly related to the chimney effect which drives the air upwards during winter period and downwards during summer. Diffusive dispersion $D \nabla^{2} x$ is in calm air weaker (only molecular), while by moving air it might be also partly turbulent and thus stronger.

The transport processes in caves are advection and diffusion (Fig. 1b). If the air in a cave is calm (upper row), only diffusion dissipates properties (in our case $\mathrm{CO}_{2}$ concentration and temperature) without displacement of their mass centres, until these are homogeneously distributed (right columns). With moderate air movement (middle row; breeze, light draft) is the mass centre of the diffused property displaced by advection and the diffusion is stronger, as there is some mixing in the air that moves. By stronger draft the advection conveys properties farther from the origin and as stronger air movement causes more turbulence, also the diffusion process is faster.

\section{APPROPRIATE VALUES AND SCALES FOR CAVES}

Scale analysis is a method of roughly estimating the values of variables and the relative importance of different processes represented by different terms in equations. In our case two variables are considered: temperature $T$ and $\mathrm{CO}_{2}$ concentration $c$. Their time changes depend on $\frac{d Q}{d t}$ and $\frac{d m_{\mathrm{CO} 2}}{d t}$, on air velocity $\vec{v}$ - with magnitude $U$, and on the size of the cave - say $L$. Additional influencing factors could be the degree of turbulence (affecting $D_{T}$ and $D_{C}$ ) ,the shape of the cave: more or less round e.g. expressed for example by the ratio between its volume $V$ and the walls' area $A$.

\section{THE SIZE OF A CAVE}

Perturbations of natural conditions during visits depend on the number of visitors, their heat and $\mathrm{CO}_{2}$ releases and on cave properties (size, shape, openness,...). In tourist caves the number of visitors per guided tour is usually up to 100 - higher numbers are accommodated by increasing the number of tours. Larger groups (around 100) are frequent in the warm season, while in winter the number is generally lower - e.g. 30 per visit. Human heat emission rate is approx. $120 \mathrm{~W}$ per person, by stronger activity also more (e.g., Mukarami et al. 2000 or EngToolBox1). So taking heat release rate of $150 \mathrm{~W} /$ person results in emissions around $15 \mathrm{~kW}$ for a group of 100 persons, or around $4.5 \mathrm{~kW}$ per smaller group of 30 persons. If the visitors stay in a particular part of a cave for 15 minutes, their released heat is $13.5 \mathrm{MJ}$ and $4 \mathrm{MJ}$, resp. The reliably detectable temperature change is $0.1^{\circ} \mathrm{C}$ and with $13.5 \mathrm{MJ}$ an air mass of $13510^{3} \mathrm{~kg}$ is heated for $0.1{ }^{\circ} \mathrm{C}$ - corresponding to a volume of $13510^{3} \mathrm{~m}^{3}$. In a round cave that would mean the diameter $r \sim 30 \mathrm{~m}$ or size (perimeter) $L=2 r \sim 60 \mathrm{~m}$. In bigger caves the human heat release causes a temperature rise below this threshold.

Similar analysis, though more uncertain due to more complex processes, could be done for $\mathrm{CO}_{2}$. Each of $n$ visitors emits $\dot{m}$ of $\mathrm{CO}_{2}$ per unit time. With relatively low human activity breathing gives around $610^{-4} \mathrm{~kg} \mathrm{CO}_{2}$ per person per minute while with normal work activity the emission is around $3010^{-4} \mathrm{~kg}$ per person per minute (Prairie \& Duarte, 2007; EngToolBox2). Thus in a case of 100 visitors $4.5 \mathrm{~kg}$ of $\mathrm{CO}_{2}$ is emitted in 15 minutes. If a typical natural concentration of $\mathrm{CO}_{2}$ in a cave is around $2000 \mathrm{ppm}$ that would increase the concentration in the bigger cave for around 20 ppm; normally at the limit of detectability for many indoor sensors, as detectability is typically a few percent of the measuring range (CO2meter.com).

What about the possible indirect impacts of visits? To allow visits to closed caves, it is necessary to open an entrance - for 100 people typically for about 5 minutes. Let us assume a breeze through the open door of $1 \mathrm{~m} / \mathrm{s}$ through the $5 \mathrm{~m}^{2}$ opening. That brings into the cave $1500 \mathrm{~m}^{3}$ of outer air. Let us take that the outer air is $10{ }^{\circ} \mathrm{C}$ warmer than the air in the cave. To increase the cave's air temperature by a detectable $0.1{ }^{\circ} \mathrm{C}, 1$ percent of outer air should mix with the air in the cave. We get the threshold volume of $V=15010^{3} \mathrm{~m}^{3}-$ similar to the previous threshold estimate. And for $\mathrm{CO}_{2}$ ? The external concentration is much smaller - about 400 ppm (for example, the NOAA Trends). Mixing one part of the air with 400 ppm with 99 parts with 2000 ppm results in 1984 ppm - after full mixing around 20 ppm decrease: a decrease similar to previously estimated increase due human breathing. Both changes initially prevail in the vicinity of the door, and later mix into the entire volume of the cave.

Another indirect impact could be illumination. Classical bulbs emit around $90 \%$ of their energy consumption as heat, so their emissions are comparable 
to that of a human (the consumption of LED light is negligible). If the number of (conventional) bulbs is comparable to the number of visitors, their impact could be included with a corresponding increase in the number of visitors.

Among indirect influences air intrusion from the outside prevails. The direct impacts of visitors are mostly negligible in caves of the size greater than 50 or $60 \mathrm{~m}$ - so we consider only smaller caves.

\section{RATES OF TEMPERATURE CHANGES DUE TO HUMAN HEAT EMISSION}

Let us assume two caves - a smaller and a larger one with the number of visitors per visit either $\mathrm{n}=30$ or 100 . Assuming that all human heat released in 15 minutes is used to increase the air temperature the heating rates $\frac{n \dot{q}}{m c_{p}}$ are as in Tab. 1.

Tab. 1: Temperature change rates $d T / d t=n \dot{q} /\left(m c_{p}\right)$ due emissions of human heat of $150 \mathrm{~W}$ per person.

\begin{tabular}{|c|c|c|}
\hline & $\mathrm{L}=10 \mathrm{~m}$ & $\mathrm{~L}=30 \mathrm{~m}$ \\
\hline$n=30$ & $3.9 \mathrm{~K} / \mathrm{h}$ & $0.14 \mathrm{~K} / \mathrm{h}$ \\
\hline$n=100$ & $12.9 \mathrm{~K} / \mathrm{h}$ & $0.48 \mathrm{~K} / \mathrm{h}$ \\
\hline
\end{tabular}

The values in Tab. 3.2 are the upper limits, as the heat exchange with walls reduces these rates. This linear increase is therefore only appropriate at the very beginning of heating and for larger caves, where the time of the exchange with the walls is long - see later in 3.4! Also, visitors normally stay at a certain location less than 15 minutes.

\section{TIME CHANGES DUE TO ADVECTION AND TURBULENT MIXING}

In partly open caves advection from the outside with a breeze or draught may cause an important change. If we know the air velocity $U$, the size of the cave $L$ and the temperature difference $\Delta T$, then $(U / L) \cdot \Delta T$ can be used to roughly estimate the magnitude of $-\vec{v} \cdot \nabla T$ and the inverse value of $L / U$ roughly describes the time in which the advection process with velocity $U$ affects a location at the distance $L$. Similarly for $\mathrm{CO}_{2}:(U / L) \cdot \Delta c$.

After an abrupt air intrusion into a certain location of an otherwise closed cave, the conditions first change only locally. Then the initial local disturbance is spread around with turbulent mixing: $D_{T} \nabla^{2} T$ and $D_{c} \nabla^{2} c$.

The magnitudes can be evaluated as $\left(D_{T} / L^{2}\right) \cdot \Delta T$ and $\left(D_{c} / L^{2}\right) \cdot \Delta c$. The inverse values $L^{2} / D$ describe the time for the diffusion processes to affect locations $L$ away. $L^{2} / D$ does not describe how quickly the perturbations at the origin are reduced (that will be assessed in section below).

The fact that both advection and diffusion estimates are dependent on $\Delta T$ and $\Delta c$ allows us to compare the time rates of both processes: $U / L$ vs. $D / L^{2}$. We again take one small and one larger cave: $L \sim 10 \mathrm{~m}$, and $L \sim$ $30 \mathrm{~m}$. Eddy diffusivity $D$ is far from being constant: it depends on the spatial scale of the process, on the rate of turbulence which depends on velocity and on hydrostatic stability. Values of $D_{T}$ in the boundary layer range from less than $1 \mathrm{~m}^{2} / \mathrm{s}$ to a few $1 \mathrm{~m}^{2} / \mathrm{s}$ (Pasquill 1962; Tennekes \& Lumley 1972; Obukhov 1971). To avoid all complicated arguments, we use a constant value $D_{T}=1 \mathrm{~m}^{2} / \mathrm{s}$. For these values the timescale estimates are shown in Tab. 2 .

Tab. 2: Timescales for effects of advection and eddy mixing to reach over a distance $L$ for smaller and bigger caves with very weak and moderate airflow, for $D_{T}=1 \mathrm{~m}^{2} / \mathrm{s}$.

\begin{tabular}{|c|c|c|c|c|}
\hline \multicolumn{2}{|c|}{ timescale } & $\begin{array}{c}L= \\
10 \mathrm{~m}\end{array}$ & $L=30 \mathrm{~m}$ & \\
\cline { 1 - 4 } advective & $L / U$ & $1.7 \mathrm{~min}$ & $5 \mathrm{~min}$ & \multirow{2}{*}{$U=0.1 \mathrm{~m} / \mathrm{s}$} \\
\cline { 1 - 4 } diffusive & $L^{2} / D_{T}$ & $1.7 \mathrm{~min}$ & $15 \mathrm{~min}$ & \\
\cline { 1 - 4 } advective & $L / U$ & $0.17 \mathrm{~min}$ & $0.5 \mathrm{~min}$ & \multirow{2}{*}{$U=1 \mathrm{~m} / \mathrm{s}$} \\
\cline { 1 - 3 } diffusive & $L^{2} / D_{T}$ & $1.7 \mathrm{~min}$ & $15 \mathrm{~min}$ & \\
\hline
\end{tabular}

Diffusive timescales depend only on a cave's size, while the advective ones depend on velocity and on size and are in all cases close to one minute. For a very weak air flow and for smaller spatial dimensions, the timescales of advection and mixing are similar. They differ the most in the case of stronger air movement in larger caves.

Rates of changes due to both processes depend on the above timescales and on the differences between the values of temperature and $\mathrm{CO}_{2}$ concentration in a cave and outside. Large temperature differences can be expected in summer and winter being positive in the first case, and negative in the other. Intrusion of the air from outside always essentially decreases the $\mathrm{CO}_{2}$ concentration.

\section{EXCHANGES WITH CAVES' WALLS}

Temperature differences between the cave air and cave's walls are of the order of $0.1 \mathrm{~K}$. But the walls may still be considered as sources or sinks of heat and $\mathrm{CO}_{2}$ for the air in a cave: $\frac{d T}{d t}=-\frac{h_{T}}{m c_{p}} A\left(T-T_{w}\right)$ and similarly for concentration c: $\frac{d c}{d t}=-\frac{h_{c}}{m} A\left(c-c_{w}\right)$. Here $h_{T}$ and $h_{C}$ are the overall heat and mass transfer coefficients between air and solid rock walls through a laminar boundary layer and further into the rock, and $A$ is the area of the walls. 
For a multilayer system (laminar air boundary layer, rock, eventual cracks, ... ) the overall transfer coefficient $h_{T}$ depends on properties of the layers: $\frac{1}{h_{T}}=\frac{1}{h_{\delta}}+\frac{1}{h_{w}}+\cdots$ and may be much smaller than for $h_{\delta}$ boundary layer alone ( $h_{w}$ denotes the one for walls). Boundary layer transfer coefficient $h_{\delta}$ depends on air velocity, on degree of turbulence. According to different data (Strnad 1992; Gupta \& Roy 2007; Chavez-Galán et al. 2014; EngToolBox3) but none from caves - in calm air $h_{\delta}$ ranges from around 1 to around $10 \mathrm{Wm}^{-2} \mathrm{~K}^{-1}$. As in closed caves the air is very calm and not knowing the appropriate value we will for now apply the lower value of $1 \mathrm{Wm}^{-2} \mathrm{~K}^{-1}$.

The sources/sinks of $\mathrm{CO}_{2}$ and the exchange with walls need some additional explanation. The main input of $\mathrm{CO}_{2}$ into caves is by $\mathrm{CO}_{2}$ enriched rainwater during percolation from the surface through soils rich in decomposed organic matter (Prelovšek 2012). Thus concentrations in caves are high, and under natural conditions rather constant. From wet walls $\mathrm{CO}_{2}$ is in general released into cave air (occasionally also readsorbed): the process depends on non-equilibrium of a system $\mathrm{H}_{2} \mathrm{O}-\mathrm{CO}_{2}-\mathrm{CaCO}_{3}$. If the $\mathrm{CO}_{2}$ concentration in cave air is lower than the equilibrium one, part of
$\mathrm{CO}_{2}$ is released from the water on wet walls (being previously bound in $\mathrm{HCO}_{3}^{-}$) into the air resulting in calc-sinter formation. When the process is reversed the consumption of $\mathrm{CO}_{2}$ on walls dissolves calcite $\mathrm{CaCO}_{3}$ from the rock resulting in $\mathrm{HCO}_{3}{ }^{-}$and water becomes corrosive (Dreybrodt et al. 2005).

Due to the much more complex $\mathrm{CO}_{2}$ exchange processes between the air in the caves and the caves (mostly wet, several chemical reactions of air-waterrock), experimental data on $\mathrm{CO}_{2}$ exchange are scarce. However, from the Reynolds analogy which states that the exchange processes through the thin boundary layer of the air at the wall should be similar, one estimate for $h_{c}$ involving air density and heat capacity suggests its value to be above $110^{-3} \mathrm{~ms}^{-1}$, (Baehr \& Stephan 2006, p. 85) and the other involving mass diffusivity (EngToolBox4) and heat conductivity below that value (Baehr \& Stephan 1998, p. 303; EngToolBox4 2020). Thus we estimate $h_{c} \approx 110^{-3} \mathrm{~ms}^{-1}$.

As $c_{p} / h_{T} \approx h_{c}$ both timescale estimates $\rho V c_{p} /\left(A h_{T}\right)$ and $\rho V /\left(A h_{T c}\right)$ are equal: for smaller cave $(\mathrm{L}=10 \mathrm{~m}$, $\mathrm{V} / \mathrm{A}=1.66 \mathrm{~m})$ around $1 / 2$ hour and for bigger $(\mathrm{L}=30 \mathrm{~m}$, $\mathrm{V} / \mathrm{A}=5 \mathrm{~m}$ ) around 1.4 hour.

\section{TEMPERATURE AND $\mathrm{CO}_{2}$ IN CAVES}

In caves that are wide open to the external environment, external daily and seasonal changes prevail over (much smaller) anthropogenic impacts. For such caves, only reduced amplitude and phase shift are worth to be considered. The deeper a location in the cave, the smaller is the amplitude, and the longer is the time lag. Processes connecting the cave with the external environment are advection and eddy (turbulent) diffusion, while the influence of the walls of the cave damps the external influences.

Another extreme example is a completely closed cave without any wind or air draught. In such caves, natural conditions are stable so the net exchanges with walls are zero. The only disruption (e.g., breeze, draught) occurs when an entrance to the cave is opened for visitors and some of the outer air can intrude into the cave. Once the door is closed, the air will calm down again. For the air as a whole in such a cave initially the diffusion dominates, and then the exchange with walls is the only process that leads to natural conditions.

\section{LOCATIONS IN OPEN CAVES}

Wide open caves are affected by outer weather and/or seasonal changes. Changes in temperature outside are often close to sinusoidal: $T_{\text {out }}=\bar{T}-\Delta T_{\text {out }} \cos (\omega t-\varphi)$ on daily and on seasonal scale. In the case of quiet weather advection may be negligible; then the equation describing time and space characteristics is the well-known diffusion equation:

$\frac{\partial T}{\partial t}=D_{T} \nabla^{2} T$

and

$\frac{\partial c}{\partial t}=D_{c} \nabla^{2} c$.

for which local temperature variations $T(t, x)$ at a distance $x$ from the entrance are:

$T(x, t)=\bar{T}-\Delta T_{\text {out }} e^{-x \sqrt{\frac{\omega}{2 D_{T}}}} \cdot \cos \left(\omega t-\varphi-x \sqrt{\frac{\omega}{2 D_{T}}}\right)$

(see e.g., Pasquill 1974; Lismonde 2002b). The amplitude at the distance $\mathrm{x}$ decreases exponentially as $e^{-x \sqrt{\frac{\omega}{2 D_{T}}}}$, while the time delay of the phase is $\delta t(x)=x \sqrt{\frac{1}{2 \omega D_{T}}}$. 
The deeper the location, the smaller are the variations and with a larger phase shift. Daily and seasonal temperature changes are commonly known, so it may be worth only mentioning that $\mathrm{CO}_{2}$ concentration in the external environment varies daily as well as annually, mainly due to vegetation (Chapman et al. 1954; Buchmann et al. 1996; NOAA CO2).

\section{THE CLOSED CAVE}

In a completely closed cave there is no air movement and no turbulence, so $-\vec{v} \cdot \nabla T=0$ and $D_{T} \nabla^{2} T=0$. If there are no heat sources $T=$ const. Such temperature is the natural temperature of the closed cave $T_{n a t}$, qeual to the temperature of walls $T_{W}$; similarly also for $\mathrm{CO}_{2}$ concentration:

$$
T=T_{\text {nat }}=T_{w}=\text { const. and } c=c_{\text {nat }}=c_{w}=\text { const } .
$$

If visitors enter the closed cave without any influence of the outside air (e.g., the entrance with double doors), the only sources of anthropogenic emissions are $\frac{n \dot{q}}{m c_{p}}$ and $\frac{n \dot{c}}{m}$. . At the beginning the temperature disturbances increase almost linearly $T(t) \approx \frac{n \dot{q}}{m c_{p}} t$, but very soon the exchange with the walls that depends on temperature difference starts and the increase becomes slower. The two equations are:

$$
\frac{\partial T}{\partial t}=\frac{n \dot{q}}{m c_{p}}-\frac{h_{T} A}{m c_{p}}\left(T-T_{w}\right)
$$

and

$$
\frac{\partial c}{\partial t}=\frac{n \dot{c}}{m}-\frac{h_{c} A}{m}\left(c-c_{w}\right) .
$$

Such linear nonhomogeneous equations are well known and using the initial $T_{\text {nat }}$ and the asymptotic $T_{\infty}$ value (for $t \rightarrow \infty: T_{\infty}=T_{n a t}+\frac{n \dot{q}}{h_{T} A}$ ) the solution, with time $t$ running from the start of the visit to its end at $t_{1}$, is:

$T(t)=T_{n a t} e^{-t / \tau_{T}}+T_{\infty}\left(1-e^{-\frac{t}{\tau_{T}}}\right)=T_{n a t}+\frac{n \dot{q}}{h_{T} A}\left(1-e^{-\frac{t}{\tau_{T}}}\right), \tau_{T}=\frac{\rho V c_{p}}{h_{T} A}$

and similarly for concentration $c$

$$
\begin{aligned}
& c_{n a t} e^{-t / \tau_{c}}+T_{\infty}\left(1-e^{-\frac{t}{\tau_{c}}}\right)= \\
& =c_{n a t}+\frac{n \dot{q}}{h_{c} A}\left(1-e^{-\frac{t}{\tau_{c}}}\right), \tau_{T}=\frac{\rho V}{h_{c} A} .
\end{aligned}
$$

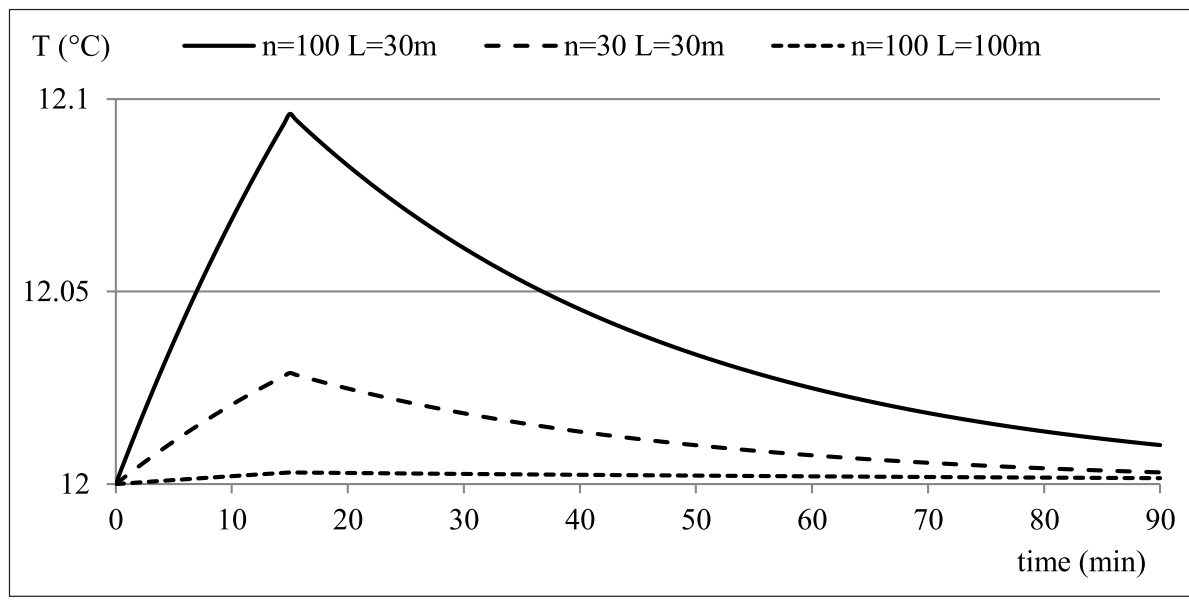

Fig. 2: Temperature increase during the 15 minutes stay of $n=100$ or $n=30$ visitors in a round closed cave of size $L=30 \mathrm{~m}$ or $L=100 \mathrm{~m}$, followed by a decrease after they leave the cave for $h_{T}=1 \mathrm{Wm}^{-2} \mathrm{~K}^{-1}$. 
Maximum perturbation temperature depends on the number $n$ of visitors and on duration $t_{1}$ of their stay in the cave: $T_{1}\left(t_{1}\right)=T_{n a t}+\frac{n \dot{q}}{h_{T} A}\left(1-e^{-\frac{t_{1}}{\tau_{T}}}\right)$. The higher the number of visitors and the smaller the cave, the higher the temperature. When visitors leave the site, only the exchange with walls remains and the temperature starts to recover towards natural conditions: $T(t)=T_{\text {nat }}+\left(T_{1}-T_{\text {nat }}\right) e^{-\frac{t-t_{1}}{\tau_{T}}}$. An example of such an increase and decrease for a round cave is given in Fig. 2.

Essential increases happen only in smaller caves with many visitors. Recovery back to natural conditions is quicker in smaller caves ( $\tau_{T}$ about $30 \mathrm{~min}$ ), and slower in bigger ones: ( $\tau_{T}$ about $\left.80 \mathrm{~min}\right)$.

\section{A SHORT DRAUGHT INTO A CLOSED CAVE}

If a closed cave is arranged for visits, the entrance must open for at least a short time. When temperature difference between the cave and the external environment is big and by proper geometry of the cvave, the outside air may enter the cave (or the inner air may leave it, e.g., Gregorič et al. 2014), what causes local disturbance $T_{0}$ near the entrance. After closing the door the perturbation spreads around the entire cave by turbulent mixing. We have already introduced the diffusion equation $\frac{\partial T}{\partial t}=D_{T} \nabla^{2} T$. Its solution for a point source is $\Delta T(r, t)=\frac{\Delta T_{o}}{2 D_{T} t} e^{-\left(r^{2} / 4 D_{T} t\right)}$. From Fig. 3 we learn that for diffusivity $D_{T}=1 \mathrm{~m}^{2} \mathrm{~s}^{-1}$ already after a short period of time - about 1 minute - the temperature is practically uniform throughout the cave. For larger distances (in bigger caves) the difference in temperature evens out in slightly longer time - but still only in a couple of minutes: e.g. at a distance of $30 \mathrm{~m}$ the maximum is reached after 3.5 minutes (the increase is negligibly small, so that the line can not be distinguished from the abscissa in Fig.3)..

\section{A SIMPLIFIED GENERAL CASE}

In partially open caves, both advective and diffuse exchanges with the external environment depend on the differences between the cave and the outside environment. Both effects could thus be expressed with one single term: for the temperature $-\frac{K_{T}}{m c_{p}}\left(T-T_{\text {out }}\right), K_{T}$ representing both exchanges; and similarly for $\mathrm{CO}_{2}$. Together with exchanges with walls and with source, such simplified equations read as:

$$
\begin{aligned}
& \frac{\partial T}{\partial t}=\frac{n \dot{q}}{m c_{p}}-\frac{h_{T} A}{m c_{p}}\left(T-T_{w}\right)-\frac{K_{T}}{m c_{p}}\left(T-T_{\text {out }}\right), \\
& \frac{\partial c}{\partial t}=\frac{n \dot{m}}{m}-\frac{h_{c} A}{m c}\left(c-c_{w}\right)-\frac{K_{c}}{m}\left(c-c_{\text {out }}\right) .
\end{aligned}
$$

Taking $K_{T}=0$ and $K_{c}=0$ they describe also the cases of closed caves. When there are no visitors $(n=0)$, the constant natural temperature of a partly open cave is the weighted average between the temperature of walls and the outer temperature:

$$
T_{\text {nat_po }}=\frac{h_{T} A T_{W}+K_{T} T_{\text {out }}}{h_{T} A+K_{T}} ; n=0 .
$$

If there are some constant sources in caves, such as energy-using equipment or longer lasting visits such as social events, another higher value stationary temperature might be reached:

$$
T_{n \dot{q}}=\frac{n \dot{q}+h_{T} A T_{w}+K_{T} T_{o u t}}{h_{T} A+K_{T}}=T_{n a t \_p o}+\frac{n \dot{q}}{h_{T} A+K_{T}} .
$$

As it takes a long time $(t \rightarrow \infty)$ to reach this constant value, $\frac{n \dot{q}}{h_{T} A+K_{T}}$ is the upper limit for such a temperature increase.

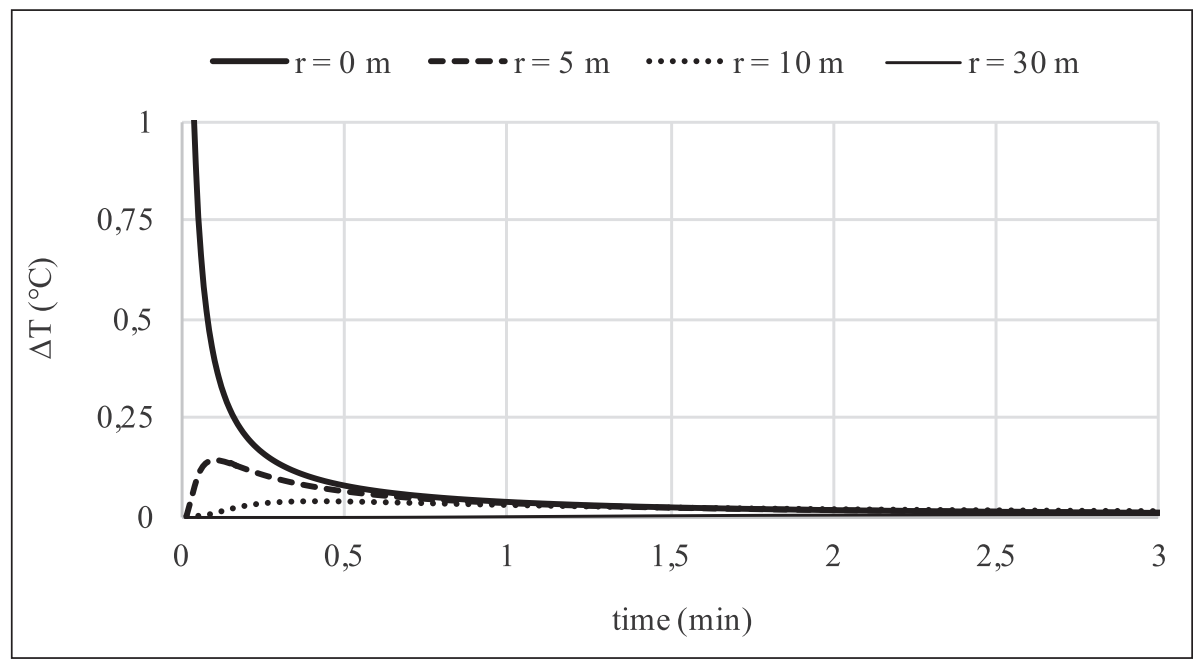

Fig. 3: Time evolution of perturbations $\Delta T(r, t)$ during the first 3 minutes at different distances $r$ from the origin of perturbation at $r=0$ for diffusivity $D_{T}=1 \mathrm{~m}^{2} / \mathrm{s}$ and for initial $\Delta T_{0}=+5^{\circ} \mathrm{C}$. 


\section{CONCLUSIONS}

A simple advection-diffusion equation is used to describe processes that govern temperature and $\mathrm{CO}_{2}$ equilibrium values in a cave, their time courses during visits, as well as exponential recoveries after visitors have left the cave.

In closed caves natural conditions are reached by the equilibrium of heat and mass exchange between the cave's walls and the air in it. In semi-open caves there is also some exchange with the outer environment. The exchange with outside air normally causes an increase of temperature during the warm part of the year and diminishes it during winter. For $\mathrm{CO}_{2}$ that is not the case: as the concentration in cave air is for an order of magnitude higher than outside, the eventual breeze or draught always diminishes the $\mathrm{CO}_{2}$ concentration. In semi-open caves natural conditions are the weighted average of the values at walls and of outer air values. The more a cave is closed, the more important is the exchange with walls, and the more it is open, the more the influences from the outside prevail. Therefore, in largely open caves the values are rather close to the outer ones (but still different from those - as it is still a cave).

Anthropogenic heat and $\mathrm{CO}_{2}$ emissions increase temperature and $\mathrm{CO}_{2}$ concentration in caves. The amplitude of these increases depends on the number of visitors, their physical activity and the duration of their visit in the cave, on the cave's size, its geometry (volume, walls) and in partially open caves also on exchanges with outside air. In caves bigger than $L \sim 50 \mathrm{~m}$ human impacts are negligible even for greater groups of visitors and even in closed caves.

The direct impacts of visits (anthropogenic heat and $\mathrm{CO}_{2}$ emissions) cause a linear increase in time, while exchanges with walls and with external air show exponential time dependencies. After the visits, when there are no more emissions, perturbations decrease exponentially.

Through the open door the outer air may break into the cave, causing a local disturbance near the entrance. This perturbation first spreads around the cave with a rather fast eddy diffusion, followed by a slower return to natural conditions

Several variables are often monitored in caves. Using their time series some parameters can be evaluated, like typical times of recovery back to natural conditions, phase shifts, reductions of amplitudes, etc.

\section{ACKNOWLEDGEMENTS}

Thanks to A. Kodre for suggestions regarding the style that essentially contributed to a shorter and clearer article and to $\check{Z}$. Zaplotnik for reading the paper and check- ing it for errors. The valuable comments of the reviewers are appreciated as well

\section{REFERENCES}

Badino, G., 1995: Fisica del clima sotterraneo.- Mem. Ist. Ital. Speleo. 7, ser II, pp. 136, Bologna.

Baehr, H.D. \& K. Stephan, 2006: Heat and mass transfer, $2^{\text {nd }} E d$.- Springer, xxii + pp. 688, Berlin Heidelberg.

Becker, T. W. \& B. J. P. Kaus, 2016: Numerical Modeling of Earth Systems: An introduction to computational methods with focus on solid Earth applications of continuum mechanics.- [Online]Available from:http:// www-udc.ig.utexas.edu/external/becker/teaching-557.html [Accessed September $1^{\text {st }}$ 2020].

Bird, R.B., Stewart, W.E. \& E.N. Lightfoot, 2007: Transport phenomena. Revised 2nd ed.- J. Wiley \& Sons, xii + pp. 905, New York.
Buchmann, N. W., Kao. W-Y. \& J.R. Ehlenringer, 1996: Carbon dioxide concentrations within forest canopy -variation with time, stand structure, and vegetation type.- Global Change Biology, 2, 421-432. https://doi.org/10.1111/j.1365-2486.1996.tb00092.x

Chapman, H.W, Gleason, L.S. \& W.E. Loomis, 1954: The carbon dioxide content of field. air.- Plant physiology, 29, 500-503. https://doi.org/10.1104/pp.29.6.500

Chávez-Galán, J., Almanaza, R. \& N. Rodríguez-Cuevas, 2014: Convective heat transfer coefficients: experimental estimation and its impact on thermal building design for walls made of different mexican 
building materials.- Concr. cem. investig. Desarro, $5,2,26-3$.

$\mathrm{CO}_{2}$ meter, 2020: $\mathrm{CO} 2$ Sensor Measurement Range, Accuracy and Precision.-[Online] Available from: https:// www.co2meter.com/blogs/news/170700807-co2measurement-range-why-it-matters [Accessed September $\left.20^{\text {th }} 2020\right]$

Covington, M.D., 2015: The importance of advection for CO dynamics in the karst critical zone: An approach from dimensional analysis.- In: Feinberg, J., Gao, Y. \& E.C. Alexander Jr. (eds.) Caves and Karst Across Time. Geological Society of America Special Paper, 516, pp. 113-127. https://doi. org/10.1130/2015.2516(09)

Dreybrodt, W., 2011:Comments on processes contributing to the isotope composition of ${ }^{13} \mathrm{C}$ and ${ }^{18} \mathrm{O}$ in calcite deposited to sepleothems.-Acta carsologica, 40, 233-238. https://doi.org/10.3986/ac.v40i2.8

Ek, C. \& J. Godissart, 2014: Carbon dioxide in cave air and soil air in some karstic areas of Belgium. A prospective view.- Geologica Belgica, 17, 1, 102-106.

EngToolBox1 2020: Met-Metabolic Rate.- Online] Available from: http://www.engineeringtoolbox.com/ met-metabolic-rate-d_733.html [Accessed September $20^{\text {th }} 2020$ ]

EngToolBox2, 2020: Carbon Dioxide Emission from People [Online] Available from: https://www.engineeringtoolbox.com/co2-persons-d_691.html [Accessed September $20^{\text {th }} 2020$ ]

EngToolBox3, 2020: Overall Heat Transfer Coefficien[Online] Available from: https://www.engineeringtoolbox.com/overall-heat-transfer-coefficient-d_434.html [Accessed September 20 ${ }^{\text {th }} 2020$ ]

EngToolBox4, 2020: Air - Diffusion Coefficients of Gases in Excess of Air [Online] Available from: https:// www.engineeringtoolbox.com/air-diffusion-coefficient-gas-mixture-temperature-d_2010.html [Accessed September 20th 2020]

Faimon, J. \& M. Lièbinská, 2010: Carbon dioxide in the soils and adjacent caves of the Moravian Karst.- Acta carsologica, 39, 3, 463-475. https://doi.org/10.3986/ ac.v39i3.76

Fernández Cortés., Á, 2004: Caracterización microclimática de Cavidades y análisis de la influencia antrópica de su uso turístico.- PhD Thesis, Univesidad de Almería, pp. 425.

Dreybrodt, W., Gabrovšek, F. \& M. Perne, 2005: Condensation corrosion: A theoretical approach.- Acta carsologica, 34, 317-348. https://doi.org/10.3986/ ac.v34i 2.262

Gabrovšek, F. \& A. Mihevc (Eds.), 2009:17 th International Karstological Schoool "Classical Karst", Postojna 2008. Cave climate : guide book \& abstracts.-
Karst Research Institute, Scientific Research Centre of the Slovenian Academy of Sciences and Arts, pp. 92.

Gregorič, A., Vaupotič, J. \& S. Šebela, 2014: The role of cave ventilation in governing cave air temperature and radon levels (Postojna Cave, Slovenia).-International journal of climatology, 34, 1488-1500. https:// doi.org/10.1002/joc.3778

Gunn, J. (Ed.), 2004: Encyclopedia of Caves and Karst Science.- Fitzroy Dearborn, New York London, pp. xx $+1940$

Gupta, H. K. \& S. Roy, 2007: Geothermal Energy: An Alternative Resource for the 21st Century 1st Edition.Elsevier Science, pp. 292.

Kundu, P.K. \& I.M. Cohen, 2002: Fliud mechanics, $2^{\text {nd }}$ Ed.- Acad. Press, pp. xxiv + 730. San Diego.

Lismonde, B., 2002a: Climatologie du monde souterrain. Tome 1 Vents des ténèbres.- Édition du Comité Départemental de Spéléologie de Isère, pp. 168, Grenoble.

Lismonde, B., 2002b: Climatologie du monde souterrain. Tome 2 Aérologie des Systèmes Karstiques.- Édition du Comité Départemental de Spéléologie de Isère, pp. 362, Grenoble.

Milanolo, S. \& F. Gabrovšek, 2009: Analysis of carbon dioxide variations in the atmosphere of Srednja Bijambarska Cave, Bosnia and Herzegovina.Boundary layer meteorol., 131, 479-493. https://doi. org/10.1007/s10546-009-9375-5

Murakami, S., Kato, S. \& J. Zeng, 2000: Combined Simulation of Airflow, Radiation and Moisture Transport for Heat Release from a Human Body.- Build. Environ., 35, 6, 489-500. https://doi.org/10.1016/S03601323(99)00033-5

NOAA Trends, 2020: Trends in Atmospheric Carbon Dioxide.- [Online] Available from: from https://www. esrl.noaa.gov/gmd/ccgg/trends/monthly.html [Accessed September $20^{\text {th }} 2020$ ]

NOAA CO2, 2020: How we measure background $\mathrm{CO} 2$ levels on Mauna Loa.- [Online] Available from: from https://www.esrl.noaa.gov/gmd/ccgg/about/ co2_measurements.html [Accessed September $20^{\text {th }}$ 2020]

Obukhov, A.M., 1971: Turbulence in an atmosphere with a non-uniform temperature.- Boundary layer meteorol., 2, 7-29. https://doi.org/10.1007/BF00718085

Pasquill, F., 1962: Atmospheric diffusion : the dispersion of wind borne material from industrial and other sources.- Van Nostrand, pp. XII + 297, London.

Prairie, Y.T, \& C. M. Duarte, 2007: Direct and indirect metabolic $\mathrm{CO} 2$ release by humanity.- Biogeosciences, 4, 215-217.

Prelovšek, M., 2012: The dynamics of the present-day spe- 
leogenetic processes in stream caves of Slovenia.- ZRC Publishing (Carsologica), pp. 152.

Prelovšek, M., Šebela, S. \& J. Turk, 2018:Carbon dioxide in Postojna Cave (Slovenia), spatial distribution, seasonal dynamics and evaluation of plausible sources and sinks.- Environmental earth sciences, 77, 15 https://doi.org/10.1007/s12665-018-7459-6

Sallstedt, Th., Ivarsson, M., Lundberg, J., Sjöberg, R. \& J.R Vidal Romaní, 2014: Speleothem and biofilm formation in a granite/dolerite cave, Northern Sweden.- International Journal of Speleology, 43, 305313. https://doi.org/10.5038/1827-806X.43.3.7

Spiegelman, M., 2000: Miths and Methods in Modelling, Chapter 1: Conservation Equations.- [Online] Available from: from www.ldeo.columbia.edu/ mspieg/ $\mathrm{mmm} /$ Conserveq.pdf [Accessed September 20 2020]
Strnad, J., 1992: Led in voda.- Presek, 19, 204-208.

Šebela, S. \& J. Turk, 2011: Local characteristics of Postojna Cave climate, air temperature, and pressure monitoring.- Theoretical and applied climatology, 105, 371-386. https://doi.org/10.1007/s00704-0110397-9

Tennekes, H. \& J.L. Lumley, 1972 : A first course in turbulence.- The MIT Press, pp. XII+300, Cambridge, Mass.

Witelski, T. \& M. Bowen, 2015: Methods of Mathematical modelling - Continuous systems and Differential equations.- Springer, pp. xviii+305. https://doi. org/10.1007/978-3-319-23042-9 